the Department of Computer Science and Economic Cybernetics, Vinnytsia National Agrarian University (21008, 3. Sonyachna str, Vinnytsia, e-mail: urnata@vsau.vin.ua).

ЮРЧУК Наталия Петровна - кандидат экономических наук, доцент кафедры компьютерных наук и экономической кибернетики, Винницкий национальный аграрный университет (21008, г. Винница, ул. Солнечная, 3, еmail: urnata@vsau.vin.ua).

\author{
МАРКЕТИНГ ПЕРСОНАЛУ \\ ЯК ІНСТРУМЕНТ \\ РЕАЛІЗАЦЇ̈ \\ КАДРОВОЇ ПОЛІТИКИ \\ ПІДПРИЕМСТВА
}

ГЕРМАНЮК Н. В., кандидат економічних наук, старший викладач кафедри аграрного менеджменту та маркетингу, Вінницький національний аграрний університет (м. Вінниця)

У статті розглянуто сутність та значення маркетингу персоналу як інструменту впровадження кадрової політики. Установлено, що це адміністративна діяльність, спрямована на задоволення підприємства робітниками, які формують його стратегічний потенціал і допомагають вирішувати конкретні завдання. Отже, маркетинг персоналу - ие вид організаційного управління, зорієнтований на забезпечення якісних $i$ кількісних організаційних потреб у трудових ресурсах.

Виявлено, щуо маркетингу персоналу притаманні дві основні функиії-інформаційна та комунікаційна. Перша з них визначається створенням бази даних під час планування кадрової політики, інша - націлена на реалізацію шляхів задоволення потреб у працівниках, а також формування гарного іміджу підприємства.

Обтрунтовано, що система маркетингових даних політики кадрів - ие загальний обмін інформацією, яка забезпечує проведення якісного аналізу і планування діяльності. 3'ясовано, щзо джерелами таких даних є: основні й додаткові навчальні програми ЗВО, курсів, служб зайнятості; аналітичні матеріали державних органів; відомості бірж праџі; спещіалізована література з працевлаштування; рекламні бромури конкурентів.

Досліджено внутрішні й зовнішні чинники, щзо характеризують сутність маркетингу персоналу. Отже, внутрішні чинники визначаються можливістю керівництва впливати на ситуачію з управління підприємством. Зовнішні - є умовами, на які підприємству самостійно вплинути не під силу. Автором запропоновано основні напрями з удосконалення маркетингової діяльності стосовно кадрового управління.

Також виявлено, щзо головними завданнями маркетингу персоналу підприємства є: аналіз ринку праці з метою виявлення вимог сьогодення і майбутнього щуодо кількісно-якісного штатного складу; дослідження тенденцій виробничого зростання для ефективного спорядження нових робочих місць та потреб кадрової політики; пошук $і$ набір робітників, які відповідають організаційним запитам.

Ключові слова: маркетинг персоналу, підприємство, кадрова політика, трудові ресурси, планування, найм.

Табл. : 3. Літ. : 13. 


\title{
PERSONNEL MARKETING AS TOOL OF REALIZATION OF STAFFING POLICY ON THE ENTERPRISE
}

\author{
GERMANIUK Natalia, \\ Senior Lecturer of the Department of Agrarian Management, \\ Vinnytsia National Agrarian University
} (Vinnytsia)

This article discusses the essence and importance of marketing of personnel as a tool for implementation of staff policy. Established, that it represents an administrative activity, aimed at satisfying of company by workers, which form its strategic potential and help to solve specific problems. Namely, staff marketing is a type of organizational management, focused on providing qualitative and quantitative organizational requests in the workforce.

It was revealed that marketing personnel has two main functions - informational and communicational. The first of these is determined by the creation of the database during the planning of personnel policy, the other one is aimed at realization of ways of satisfaction the needs of workers, as well as forming a good image of the enterprise. of information, which provides for quality analysis and planning of activities. The sources of such data are: basic and additional curricula of universities, courses and employment services; analytical materials of state bodies; information exchange of labor; specialized literature on employment; advertising brochures of competitors.

The internal and external factors characterizing the essence of marketing of personnel are investigated. Consequently, internal factors are determined by the ability of enterprise to influence the management of an enterprise. External, in turn, there are the conditions on which the company itself can't influence. The author proposes the main directions for improvement of marketing activities in relation personnel management.

Established also that the main objectives of marketing personnel of the enterprise are: analysis of the labor market in order to detect current and future needs for quantitatively-qualitative staff; research of production growth trends for timely provision of new jobs and for satisfaction of personnel policy needs; search and hiring of employees who meet organizational requirements.

Keywords: marketing of personnel, enterprise, staff policy, workforce, planning, hiring.

Tab. : 3. Lit. : 13.

\section{МАРКЕТИНГ ПЕРСОНАЛА КАК ИНСТРУМЕНТ РЕАЛИЗАЦИИ КАДРОВОЙ ПОЛИТИКИ НА ПРЕДПРИЯТИИ}

\author{
ГЕРМАНЮК Н. В., \\ кандидат экономических наук, \\ стариий преподаватель кафедры \\ аграрного менеджмента и маркетинга, \\ Винницкий национальный аграрный университет
} (2. Винница)

В статье рассмотрень первооснова и значение маркетинга персонала как инструмента внедрения кадровой политики. Определено, что он представляет собой административную деятельность, направленную на удовлетворение потребностей 
предприятия в работниках, которые формируют его стратегический потенциал и помогают решать конкретные задачи. А именно, маркетинг персонала - это вид организационного управления, сориентированный на обеспечение качественных и количественных организационных запросов в трудовых ресурсах.

Установлено, что персонал-маркетингу присущии две основные фуункции: информачионная и коммуникативная. Первая из них определяется созданием базы данных во время планирования кадровой политики, другая - направлена на реализацию возможностей удовлетворения потребностей в работниках, а также формирования хорошего имиджа предприятия.

Обосновано, что система маркетинговых данных политики кадров представляет собой общий информационный обмен, который обеспечивает проведение качественного анализа и планирование деятельности. Выяснено, что источниками таких материалов могут служсть: основные и дополнительные учебные программы вузов, курсов, служб занятости; аналитические сведения государственных органов; ведомости бирж труда; специиализированная литература по трудоустройству; рекламные брошюры конкурентов.

Исследованы внутренние и внешние факторы, которые характеризуют сущность персонал-маркетинга. Так, внутренние факторы определяются возможностью руководства влиять на управление предприятием. В свою очередь, внешние - представляют собой условия, на которые администрация повлиять самостоятельно не способна. Автором обозначены ключевые направления относительно улучшения маркетинговой деятельности в управлении кадрами.

Также установлено, что главными задачами маркетинга персонала предприятия являются: анализ рынка труда с иелью обнаружения сегодняшних и будущих потребностей в количественно-качественном итатном составе; исследование тенденций производственного роста для своевременного обеспечения новыми рабочими местами $u$ удовлетворения запросов кадровой политики; поиск и наем работников, соответствующих организационным требованиям.

Ключевые слова: маркетинг персонала, предприятие, кадровая политика, трудовые ресурсы, планирование, наем.

Табл. : 3. Лит. : 13.

Постановка проблеми. Останнім часом в умовах наростаючої конкуренції майже на кожному підприємстві виникає гостра потреба у плануванні кількісноякісних потреб і пошуку робочої сили, що визначається категорією «маркетинг персоналу». Працівники сьогодні є важливою складовою будь-якого виду бізнесдіяльності, найбільш цінним капіталом. Наявність чіткої управлінської системи, штатних вакансій, певного стилю керівництва, дослідження стану робітників $\epsilon$ базовими передумовами формування маркетингу персоналу, який виник досить нещодавно. Отже, маркетинг персоналу - це управлінська діяльність, спрямована на організаційне забезпечення робітниками, які формують стратегічний потенціал і допомагають вирішувати конкретні завдання. Подібна активність сприяє правильному своєчасному підбору кандидатів та їхній ефективній оцінці, яка має здійснюватись на наукових принципах роботи 3 кадрами. Фундаментальною базою для розробки заходів з персонал-маркетингу слугують дані про внутрішні та зовнішні чинники, які впливають на побудову штатного складу на підприємстві. Ураховуючи актуальність теми, маркетинг- 
персоналу як інструмент впровадження кадрової політики потребує подальшого вивчення.

Аналіз останніх досліджень і публікацій. Науково-методологічні дослідження щодо втілення основних засад маркетингу персоналу, формування кадрової політики підприємств, сприяння розвитку працівників висвітлено у працях багатьох відомих закордонних і вітчизняних вчених, зокрема таких як П. Друкер [6], А. Марк [7], Е. Брайан [7], У. Беккер [7], Д. Речмен [8], М. Мескон [8], К. Боуві [8], Д. Тілл [8], Л. Балабанова [2], О. Стельмашенко [2], В. Гриньова [3; 4], Г. Писаревська [3], І. Грузіна [4], А. Сгоршин [1], Г. Калетнік [9], А. Мазур [9; 10], Р. Дмитрук [10]. Проте, основні напрями розвитку персонал-маркетингу вимагають подальшого розгляду.

Метою статті $\epsilon$ дослідження маркетингу персоналу як інструменту реалізації кадрової політики підприсмства, визначення теоретикометодологічних засад його ведення 3 виявленням шляхів подолання головних проблем і напрямів удосконалення процесу.

Виклад основного матеріалу дослідження. У сучасних умовах розвитку персонал-маркетинг можливо досліджувати як одну з головних управлінських засад, зорієнтовану на здобуття конкурентних переваг, чому сприяє використання систематизованої методики під час пошуку найбільш оптимальних рішень. Головними його спрямуваннями доцільно вважати аналіз, побудову стратегічних і тактичних планів, секторальний розподіл ринку праці, визначення вартості трудових ресурсів, стимулювання кадрів до працевлаштування, формування іміджу організації, а власним продуктом - посаду, що пропонується.

Сьогодні робітники $є$ важливим компонентом будь-якого виду бізнесдіяльності як найбільш цінний капітал підприємства. Саме цим пояснюється значна увага менеджерів до відбору та найму дійсно потрібних людей, контролю за їхнім навчанням, оцінювання поточної професійної діяльності зі встановленням відповідних розмірів оплати праці. Сукупність таких специфічних функцій має назву управління персоналом (або трудовими ресурсами). Якісний підбір кадрів і ефективне керівництво ними помітно сприяє досягненню організаційних цілей.

Уже 3 початку 90-х років управління трудовими ресурсами стає складнішим процесом, набуваючи чітко вираженого стратегічного характеру. Економіка i корпоративна культура розвиваються прискореними темпами. Інноваційні технологічні зміни спричиняють суттєву невідповідність між досвідченістю працівників і потребами підприємців. Управлінці кадрових підрозділів вирішують питання пошуку та залучення фахівців, навчання некваліфікованих робітників (молоді), збереження компетентних кадрів, надання персоналу оптимальних умов праці та гідної зарплати [8].

Маркетинг персоналу - це адміністративна діяльність, спрямована на задоволення підприємства робітниками, які формують стратегічний потенціал $\mathrm{i}$ допомагають вирішувати конкретні завдання. Йому притаманні такі функції: 
1) інформаційна, яка характеризується створенням бази даних під час розробки планів з політики кадрів;

2) комунікаційна, націлена на визначення та реалізацію шляхів задоволення потреб у робітниках і побудову гарного іміджу підприємства.

Інформаційний простір 3 управління персоналом включає: дослідження посадових вимог; аналіз загального стану господарської діяльності; вивчення ринку праці та репутації підприємства.

Система маркетингових даних кадрової політики - це комплексний обмін відомостями, що забезпечує проведення фахівцями якісного аналізу i планування, а також впровадження корисних заходів у відповідному напрямі. Джерелами такої інформації можуть бути: основні й додаткові навчальні програми закладів вищої освіти, курсів, служб зайнятості; аналітичні матеріали державних органів; відомості бірж праці; спеціалізована література 3 працевлаштування; рекламні брошури конкурентів.

Комунікаційне середовище складається 3: робітників, які представляють імідж підприємства; зовнішнього ринку праці як простору для пошуку кандидатів на посадове місце; суспільства як утворювального фактору впливу на формування думок. Втілення комунікаційних засад персонал-маркетингу відбувається за допомогою таких дій: розподіл, створення внутрішніх зв'язків, рекламування i презентаційні заходи, налагодження взаємостосунків у колективі.

Базою для реалізації ефективних заходів у процесі взаємодії з персоналом $\epsilon$ сегментування комунікаційного середовища на цільові групи (чим має займатись відділ 3 управління кадрами), яке відбувається за такими компонентами:

1) поведінковим;

2) господарським;

3) кадрового відтворення;

4) розташування у просторі тощо.

Атмосфера людських взаємин на підприємстві визначається піклуванням про збалансування внутрішніх стосунків із метою сприяння позитивному ставленню колег один до одного (виховання шанобливого ставлення) та надання можливостей для особистісного розвитку.

Серед наявних підходів із виявлення змістовності й цілей персоналмаркетингу заведено виокремлювати два суттєві принципи [13]:

1) розглядає питання у загальному значенні: кадровий склад визначається внутрішніми та зовнішніми клієнтами, маркетинг - філософською концепцією 3 управління людськими ресурсами. Метою останнього $є$ ефективне застосування трудового потенціалу шляхом забезпечення найбільш оптимальних умов праці, що покращує ії результативність, породжуючи у робітників відчуття причетності до колективної діяльності. Такий підхід базується на ринковому міркуванні, чим і відрізняється від звичайних стратегій; 
2) пояснює маркетинг персоналу достатньо однобічно - як специфічну систему з адміністрування кадрів, спрямовану на задоволення організаційних потреб у працівниках.

Маркетинговою концепцією з управління персоналом є положення, за якого одним із найбільш важливих елементів успішної реалізації поточних завдань має бути чітке виявлення:

1) професійних вимог до працівників;

2) суспільних людських потреб під час трудової активності (шляхів задоволення останніх).

У ході дослідження внутрішніх і зовнішніх чинників, які визначають змістовність маркетингу персоналу, відбувається планування та пошук ефективних шляхів спрямування діяльності, а також виявлення заходів щодо їхнього впровадження у життя [13].

Першим етапом укомплектування штату є складання планів. Адже для ефективного організаційного руху вперед доцільно мати у розпорядженні потрібних людей у визначений період часу. Планування - це базова стадія персонал-маркетингу [8]. Будь-яка неточність може обернутися підприємству відсутністю необхідної кількості робітників для забезпечення виробничого механізму, що призведе до суттєвих збитків і втрати клієнтів. 3 іншого боку, коли чисельність працівників зростає надто швидкими темпами, прибутки можуть витрачатись лише на зарплату. Поряд із цим, імовірним $є$ виникнення ситуації стосовно примусового звільнення людей, які були відібрані та пройшли навчання, на що витрачено кошти. На приклад, компанії Кремнієвої долини, які розраховували на суттєве зростання попиту на електронні деталі, найняли значну кількість робітників і незабаром мали їх звільнити, тому що очікування 3 продажу не виправдались.

Досягнення збалансованості між пропозицією та попитом у плануванні трудових ресурсів $\epsilon$ вкрай важливим чинником подальшого організаційного розвитку. Прогнозування розпочинається з оцінювання обсягів попиту, кількості та видів професій, які знадобляться у різні періоди. Наприклад, компанія, якій належить мережа магазинів спортивного інвентарю, збирається через 5-6 місяців відкрити новий. Керівництво вбачає необхідність у знаходженні директора, його заступника та продавців на повний робочий день [8]. При цьому, розпочати пошук кандидатів на управлінську вакансію потрібно терміново, а найняття продавців можна значно відкласти.

Наступним завданням прогнозування $є$ оцінювання обсягів пропозиції серед наявних працівників. У разі, якщо їх неможливо використати на новостворених робочих місцях, кадровики мають визначити ймовірні складнощі стосовно пошуку персоналу з відповідними кваліфікаційними якостями. Потім відбувається аналіз професійних функцій, який реалізується шляхом складання посадових інструкцій і вимог до претендента на робоче місце, що в результаті призводить безпосередньо до найму. 
Доповнимо, що під час планування кількісної потреби в людських ресурсах обов'язково потрібно враховувати нинішню змінність економічної ситуації. Чимало підприємств 3 метою заощадження власних засобів та розширення умов маневрування спрямовують політику кадрів на оформлення працівників зі скороченим графіком або тимчасових робітників.

На наш погляд, цікавими є статистичні дані служби зайнятості України щодо кандидатів на одне робоче місце за професійними групами. Отже, найбільша чисельність здобувачів (8 осіб) - серед законодавців, керівників та досвідчених працівників аграрної сфери, найменша (1 особа) - поміж кваліфікованих робітників з інструментом (табл. 1).

Таблиия 1

Чисельність претендентів на одне робоче місще за професійними групами в Україні, станом на 1 вересня 2017-2018 pp.

\begin{tabular}{|l|c|c|c|c|}
\hline \multirow{2}{*}{\multicolumn{1}{|c|}{ Професійна група }} & \multicolumn{2}{|c|}{$\begin{array}{c}\text { Кількість осіб на } \\
\text { 1 робоче місце }\end{array}$} & \multirow{2}{*}{$\begin{array}{c}\text { Абсолютне } \\
\text { відхилення (+, -) }\end{array}$} & $\begin{array}{c}\text { Відносне } \\
\text { відхилення } \\
\text { (\%) }\end{array}$ \\
\cline { 2 - 3 } & $2017 \mathrm{p}$. & $2018 \mathrm{p}$. & & 64,0 \\
\hline Законодавці, менеджери, керівники & 10 & 8 & -2 & 0 \\
\hline Професіонали & 2 & 2 & 0 & 75,0 \\
\hline Фахівці & 4 & 3 & -1 & 60,0 \\
\hline Технічні службовці & 5 & 4 & -1 & 54,0 \\
\hline Працівники сфери торгівлі та послуг & 5 & 3 & -2 & 50,0 \\
\hline $\begin{array}{l}\text { Досвідчені робітники сільського та } \\
\text { лісового господарства }\end{array}$ & 15 & 8 & -7 & 75,0 \\
\hline Кваліфіковані робітники з інструментом & 2 & 1 & -1 & 75,0 \\
\hline $\begin{array}{l}\text { Робітники з обслуговування, експлуатації } \\
\text { устаткування та машин }\end{array}$ & 4 & 3 & -1 & \\
\hline $\begin{array}{l}\text { Найпростіші професії (враховуючи осіб } \\
\text { без професії) }\end{array}$ & 4 & 3 & -1 & \\
\hline
\end{tabular}

Джерело: розраховано автором на основі [11]

Тепер розглянемо внутрішні й зовнішні фактори, які визначають сутність персонал-маркетингу.

Отже, внутрішні чинники характеризуються можливістю керівництва впливати на ситуацію з управління підприємством (табл. 2).

Всеосяжне і точне обчислювання наведених факторів сприяє з'ясуванню ступеня та особливостей упровадження головних орієнтирів маркетингової активності підприємства з управління кадрами. Основними заходами при цьому $\epsilon$ :

- розробка вимог до працівників (здійснюється на базі штатного розкладу, аналізу поточних і запланованих посадових обов'язків, створення бажаних якісних властивостей кандидатів);

- розрахунок ймовірних витрат на залучення та використання робочої сили;

- вибір можливих напрямів щодо покриття ступеня необхідності у трудових ресурсах.

Загалом в Україні, як бачимо зі статистичної інформації, спостерігається зменшення кількості претендентів на одну вакансію. На нашу думку, це 
пов’язано з поширенням трудової міграції вітчизняних громадян за кордон через введення безвізового режиму з $\mathrm{CC}$.

Табличяя 2

\section{Внутрішні чинники, які характеризують сутність персонал-} маркетингу

\begin{tabular}{|c|c|}
\hline Назва чиннику & Характеристика \\
\hline Організаційна мета & $\begin{array}{l}\text { Наявність конкретних цілей зумовлює чітку зорієнтованість довгострокової стратегії } \\
\text { підприємства, формуючи маркетингові кадрові заходи. }\end{array}$ \\
\hline $\begin{array}{l}\text { Фінансове } \\
\text { забезпечення }\end{array}$ & $\begin{array}{l}\text { Точні розрахунки щодо вимог і потенціалу підприємства стосовно фінансування } \\
\text { кадрової політики слугують базою для відбору альтернативних рішень протягом } \\
\text { складання планів з виявлення необхідної чисельності персоналу, головних напрямів його } \\
\text { використання та навчання. }\end{array}$ \\
\hline Трудові ресурси & $\begin{array}{l}\text { Стосується як маркетингового середовища, так і політики кадрів загалом. Фактор } \\
\text { пов'язаний з оцінюванням потенціалу співробітників, оптимальним розподілом їхніх } \\
\text { посадових обов'язків, що у змозі забезпечити успішне впровадження планування } \\
\text { персонал-маркетингу. }\end{array}$ \\
\hline $\begin{array}{l}\text { Можливі джерела } \\
\text { щодо забезпечення } \\
\text { кадрових потреб }\end{array}$ & $\begin{array}{l}\text { Вивчається як потенційно ймовірні джерела } 3 \text { відбору необхідних працівників, які } \\
\text { відповідають організаційним цілям, наявним грошовим ресурсам, ступеню } \\
\text { технологічного та інноваційного прогресу }\end{array}$ \\
\hline
\end{tabular}

\section{Джерело: [12]}

Загалом в Україні, як бачимо зі статистичної інформації, спостерігається зменшення кількості претендентів на одну вакансію. На нашу думку, це пов'язано з поширенням трудової міграції вітчизняних громадян за кордон через введення безвізового режиму з $\mathrm{CC}$.

Зовнішні чинники, які визначають змістовність маркетингу персоналу

Загальногосподарський стан та галузева активність

Технологічний розвиток

Кадрова політика конкурентів
Характеристика

Дослідження цього чинника визначає основні напрями економічного зростання, конкурентну ситуацію, ступінь взаємодії із профспілками, стан сфери освіти.

Вивчає зміну характеру і стану праці, iіi предметне спрямування, формуючи змінність вимог щодо спеціальностей і робочих місць, підготовки та перепідготовки кадрів.

Облік цього фактору допомагає уявити систему мотиваційного центру ймовірних працівників, яка визначається суспільними, виробничими стосунками на теперішній час.

Протягом розв'язання питань 3 маркетингу персоналу доцільно застосовувати відповідні законодавчі положення, легітимну базу 3 охорони праці та зайнятості населення.

Аналізування методики співпраці 3 персоналом на підприємствахконкурентах з метою побудови поведінкової стратегії, зорієнтованої на поліпшення політики управління персоналом.

$$
\text { Джерело: [12] }
$$

Маркетинг персоналу підприємства головними завданнями власної діяльності визначає:

- аналіз ринку праці з метою виявлення сьогоденних і майбутніх вимог щодо кількісно-якісного штатного складу; 
- дослідження тенденцій виробничого зростання для ефективного спорядження нових робочих місць та потреб кадрової політики;

- пошук і набір робітників, які відповідають організаційним запитам.

Отже, маркетинговий процес 3 управління персоналом формує основу 3 відтворення процедури кінцевого підбору працівників [5].

Висновки. Таким чином, сьогодні персонал-маркетинг набуває особливої актуальності, в основі чого знаходиться необхідність у забезпеченні підприємства кваліфікованими кадрами. Дослідження спрямоване, з одного боку, на задоволення якісно-кількісних потреб у працівниках, а з іншого - на кадровий розвиток.

Маркетинг персоналу - це вид організаційного управління, зорієнтований на забезпечення якісних і кількісних організаційних потреб у персоналі. Однією 3 головних його функцій $є$ процедура оцінювання професійної діяльності, ділових і особистих рис працівників. Він складається з підбору кандидатів та їхньої оцінки, що займає вкрай важливе місце у структурній співпраці з людьми i має здійснюватись на наукових принципах. Основними етапами комплектування кадрів $\epsilon$ : планування, прогнозування, аналіз професійних функцій та найм персоналу.

Фундаментальною основою для розробки дій персонал-маркетингу є дані про внутрішні та зовнішні чинники, які впливають на задоволення організаційних запитів у робітниках, а також інформація, яка публікується державними установами 3 працевлаштування, спеціалізовані матеріали 3 управління кадрами та зайнятістю населення, рекламні брошури підприємствконкурентів, навчальні програми й плани випуску фахівців.

Точний розрахунок визначених факторів виявляє ступінь та специфіку втілення головних орієнтирів стосовно удосконалення маркетингової діяльності підприємства щодо управління кадрами, сприяє формуванню основних заходів і завдань, допомагаючи в пошуку ефективних напрямів вирішення важливих питань.

\section{Список використаних джерел}

1. Егоршин А. П. Управление персоналом. Нижній Новгород: НИМБ, 2008. $346 \mathrm{c}$.

2. Балабанова Л. В., Стельмашенко О. В. Стратегічне управління персоналом підприємства в умовах ринкової економіки : монографія. Донецьк : ДонНУЕТ, 2010. 229 с.

3. Гриньова В. М., Писаревська Г. І. Управління кадровим потенціалом підприємства : монографія, Харків : Вид. ХНЕУ, 2012. 228 с.

4. Гриньова В. М., Грузіна І. А. Формування мотиваційної стратегії управління персоналом на підприємстві : монографія. Харків : ХНЕУ, 2012. $298 \mathrm{c}$.

5. Дейнека А. В., Беспалько В. А. Управление человеческими ресурсами. Москва : Дашков и К, 2017. 392 с. 
6. Друкер П. Ф. Задачи менеджмента в XXI веке: Пер. с англ. П. Ф. Друкер. Москва : Издательский дом «Вильямс», 2004. 272 с.

7. Марк А. Оценка персонала: Пер. с англ. А. Марк, Е. Брайан, У. Беккер. Київ : Вильямс, 2007. 432 с.

8. Речмен Д. Современный бизнес: Пер. с англ. Д. Речмен, М. Мескон, К. Боуви, Д. Тилл. Москва: Республика, 1995. Т 1, 431 с.

9. Калетнік Г. М., Мазур А.Г. Науково-теоретичні аспекти формування та розвитку людського капіталу в сільських територіях. Економіка, фінанси, менеджмент : актуальні питання науки і практики. 2016. № 10 (14). С. 7-25.

10. Мазур В. А., Германюк Н.В., Дмитрук Р.В. Особливості кадрової політики аграрних підприємств у сучасних умовах. Економіка, фінанси, менеджмент : актуальні питання науки і практики. 2018. № 1 (29). С. 7-20.

11. Державна служба зайнятості. Аналітична та статистична інформація. URL: https://www.dcz.gov.ua/analitics/view. (дата звернення: 12.08.2019).

12. Маркетинг персоналу. Планування кадрового потенціалу. URL: http://ni.biz.ua/9-9/60564.html. (дата звернення: 12.08.2019).

13. Організація маркетингу персоналу. URL: http://um.co.ua/8/8-6/862497.html. (дата звернення: 12.08.2019).

\section{References}

1. Ehorshyn, A. P. (2008). Upravlenye perconalom [Management of personnel] - N. Novhorod: NYMB, [in Russian].

2. Balabanova, L. V. \& Stelmashenko, O. V. (2010). Stratehichne upravlinnia personalom pidpryiemstva $\mathrm{v}$ umovakh rynkovoi ekonomiky [Strategic management of personnel of the enterprise in market economy] - Donetsk: DonNUET [in Ukrainian].

3. Hrynova, V. M. \& Pysarevska, H. I. (2012). Upravlinnia kadrovym potentsialom pidpryiemstva [Management of personnel potential of the enterprise] Kh.: Vyd. KhNEU [in Ukrainian].

4. Hrynova, V. M. \& Hruzina, I. A. (2012). Formuvannia motyvatsiinoi stratehii upravlinnia personalom na pidpryiemstvi [Formation of motivational strategy of personnel management at the enterprise] - Kh.: KhNEU, [in Ukrainian].

5. Deineka, A. V. \& Bespalko, V. A. (2017). Upravlenye chelovecheskimi resursami [Management of human resources] - M.: Dashkov \& K [in Russian].

6. Druker, P. \& (2004) Zadachi menedzhmenta v XXI veke [Tasks of management in XXI century] - M.: Vyliams, [in Russian].

7. Mark, A., Braian, E. \& Bekker, U. (2007). Otsenka personala [Staff assessment] - K.: Vyliams [in Russian].

8. Rechmen, D., Meskon, M., Bouvy, K. \& Tyll, D. (1995). Sovremennyi byznes [Modern business] - Moskva: Respublyka [in Russian].

9. Kaletnik, G. M. \& Mazur, A. G. (2016). Naukovo-teoretychni aspekty formuvannia ta rozvytku liudskoho kapitalu $\mathrm{v}$ silskykh terytoriiakh [Scientific and theoretical aspects of the formation and development of human capital in rural areas]. Ekonomika. Finansy. Menedzhment: aktualni pytannia nauky i praktyky - Economy. 
Finances. Management: current issues of science and practice, 10 (14), 7-25 [in Ukrainian].

10. Mazur, V. A., Hermaniuk, N. V. \& Dmytruk, R. V. (2018). Osoblyvosti kadrovoi polityky ahrarnykh pidpryiemstv u suchasnykh umovakh [Features of personnel policy of agrarian enterprises in modern conditions]. Ekonomika. Finansy. Menedzhment: aktualni pytannia nauky i praktyky - Economy. Finances. Management: current issues of science and practice, 1 (29), 7-20 [in Ukrainian].

11. Derzhavna sluzhba zainiatosti. Analitychna ta statystychna informatsiia [Analytical and statistical information] - Retrieved from: https://www.dcz.gov.ua/analitics/view [in Ukrainian].

12. Marketynh personalu. Planuvannia kadrovoho potentsialu [Marketing of personnel. Planning of human resource] - Retrieved from: http://ni.biz.ua/9-9/ 60564.html (data zvernennia: 12.08.2019) [in Ukraine].

13. Orhanizatsiia marketynhu personalu [Organization of marketing of personnal] - Retrived from: http://um.co.ua/8/8-6/8-62497.html (data zvernennia: 12.08.2019) [in Ukrainian].

\section{Відомості про автора:}

ГЕРМАНЮК Наталія Володимирівна - кандидат економічних наук, старший викладач кафедри аграрного менеджменту та маркетингу, Вінницький національний аграрний університет (21008, м. Вінниця, вул. Сонячна, 3, e-mail: natagermanjuk@gmail.com).

GERMANJUK Natalia - PhD (Economics), Senior Lecturer of the Department of Agricultural Management and Marketing, Vinnytsia National Agrarian University (21008, Vinnytsia, 3, Soniachna st., e-mail: natagermanjuk@gmail.com).

ГЕРМАНЮК Наталия Владимировна - кандидат экономических наук, старший преподаватель кафедры аграрного менеджмента и маркетинга, Винницкий национальный аграрный университет (21008, г. Винница, ул. Солнечная, 3, e-mail: natagermanjuk@gmail.com). 